\title{
Relationship of Seasonal Changes in Carbohydrates and Cold Hardiness in Canes and Buds of Three Red Raspberry Cultivars
}

\author{
Pauliina Palonen \\ Department of Plant Production, P.O.Box 27, FIN-00014 University of Helsinki, Finland
}

AdDitional INDEX wORDs. frost hardiness, frost resistance, $\mathrm{LT}_{50}$, Rubus idaeus, sugars, winter hardiness

\begin{abstract}
Canes of three field-grown cultivars of red raspberry (Rubus idaeus L. 'Maurin Makea', 'Ottawa', and 'Muskoka') were sampled from October to April. Carbohydrate contents of canes and flower buds were analyzed, and cold hardiness $\left(\mathbf{L T}_{50}\right)$ was determined by controlled freezing. Starch, sucrose, glucose, fructose, and minor amounts of raffinose and stachyose were present in both cane and bud tissues. Glucose and fructose were the predominant sugars in buds. In canes, the proportion of sucrose of all sugars was greater than in buds. Seasonal changes in carbohydrates were related to changes in cold hardiness and mean air temperature during a 5-day period preceding sampling. Starch decreased during fall and was barely detectable in midwinter. Soluble carbohydrates accumulated to 73 to 89 mg. $\mathrm{g}^{-1} \mathrm{dry}$ weight in canes and 113 to $131 \mathrm{mg} \cdot \mathrm{g}^{-1}$ dry weight in buds in midwinter. The most striking increase occurred in the concentration of sucrose, but glucose, fructose, raffinose, and stachyose also accumulated. There was a positive correlation between $L T_{50}$ and the amount of starch, but a negative correlation between $L_{50}$ and the amounts of total soluble carbohydrates, sucrose, glucose, and fructose. High levels of sucrose, total soluble carbohydrates, and a high ratio of sucrose to glucose plus fructose were characteristic of a hardy cultivar. Results are evidence of the importance of carbohydrate reserves, especially sucrose, on winter survival of red raspberry.
\end{abstract}

Sugars accumulate during cold hardening in woody plants, when starch is hydrolyzed to low-molecular weight carbohydrates (Sakai and Yoshida, 1968). Starch content is inversely related to the amount of soluble carbohydrates and cold hardiness in many plant species (Jennings and Carmichael, 1975; Kaurin et al., 1981; Lasheen and Chaplin, 1971; Raese et al., 1977). On the contrary, soluble carbohydrate content positively correlates with cold hardiness. In cloudberry (Rubus chamaemorus L.) there is a positive correlation between cold hardiness and the quantities of both soluble carbohydrates and sucrose (Kaurin et al., 1981). Similarly high levels of sucrose and total sugars in bark and wood, and sorbitol in the sap, are related to cold hardiness in apple [Malus sylvestris (L.) Mill. var domestica Borkh. (Mansf.)] (Ichiki and Yamaya, 1982; Raese et al., 1977, 1978). Likewise, more soluble sugars accumulate in the shoots and flower buds of a hardy peach [Prunus persica (L.) Batsch] and apricot (Prunus armeniaca $\mathrm{L}$.) cultivar than in tender ones (Lasheen and Chaplin, 1971; Tamassy and Zayan, 1982). In grape (Vitis vinifera L.), accumulation of carbohydrates is related to both bud cold hardiness and dormancy status (Wample and Bary, 1992), the high ratio of glucose plus fructose to sucrose being positively correlated with hardiness (Hamman et al., 1996). Accumulation of raffinose family oligosaccharides during cold acclimation occurs in several species, such as apple, red currant [Ribes sativum (Rchb.) Syme] (Stushnoffet al., 1993), redosier dogwood (Cornus sericea L.) (Ashworth et al., 1993), Forsythia species $[F$. Xintermedia Zabel, F. suspensa (Thunb.) Vahl] (Flinn and Ashworth, 1995), grape (Hamman et al., 1996) and Lonicera caerulea L. (Imanishi et al., 1998).

Sugar accumulation in acclimating plants may have many

Received for publication 7 Dec. 1998. Accepted for publication 20 May 1999. Financial support from the Emil Aaltonen Foundation is gratefully acknowledged. I thank Leila Keinänen for technical assistance, Irma Voipio and Leena Lindén for critical reading of the manuscript, and Deana Namuth for correcting the English. The cost of publishing this paper was defrayed in part by the payment of page charges. Under postal regulations, this paper therefore must be hereby marked advertisement solely to indicate this fact. functions. Sugars are known to lower the freezing point and increase the intracellular osmotic potential. This would reduce the amount of dehydration during extracellular freezing (Levitt, 1980). Sugars and sugar alcohols also act as colligative cryoprotectants for cell membranes and proteins by diluting electrolytes and toxic compounds that accumulate during freezing (Santarius, 1982). During dehydration stress, the hydroxyl groups of sucrose may replace water by hydrogen binding to the phospholipid head groups of the membrane (Anchordoguy et al., 1987; Crowe et al., 1987). Some sugars can preserve the structure and function of labile proteins in the absence of water (Crowe et al., 1987).

Frequent winter injury to red raspberry (Rubus idaeus) canes cause economic losses and are a primary limiting factor for expanding raspberry production in northern areas. Hence, there is a need for new, cold-hardy raspberry cultivars and for development of cultural practices that ensure winter survival of raspberry canes. Sugar accumulation may be an important factor in increased hardiness. Accumulation of soluble carbohydrates in raspberry canes during fall hardening and the decline in spring have been observed (Bennett and Weeks, 1960; Crandall et al. 1974; Jennings and Carmichael, 1975). Changes in sugar content were not associated with changes in dormancy status, but rather were induced by weather changes (Jennings and Carmichael, 1975). The raspberry genotype with lowest winter hardiness had higher proportions of its photosynthates in roots as starch and a correspondingly lower portion as sugar (Jennings and Carmichael, 1975). Premature defoliation of raspberry canes decreases both starch and sugar reserves and increases the susceptibility of bud tissues to freeze injury (Doughty et al., 1972). However, the qualitative changes in carbohydrates of raspberry canes and buds during cold acclimation have not been studied.

During the growing season, raspberry bark contains sucrose as the major translocated carbohydrate along with some glucose and fructose as breakdown products, and traces of raffinose (Burley, 1961). Sakai (1966) reported the occurrence of polyhydric alcohols ( $1.08 \%$ fresh weight, combined mannitol and sorbitol content) in 
raspberry bark tissue. In contrast, Wallaart (1980) reported that raspberry plants, like other species of Rubus L., do not contain sorbitol, a feature useful in intrafamilial classification of Rosaceae. Jennings and Carmichael (1975) found that the amount of reducing sugars in canes of three raspberry genotypes was, on average, $9.80 \%$ to $11.17 \%$ dry weight, while that of the nonreducing sugars was $2.52 \%$ to $4.24 \%$ dry weight. No detailed information on carbohydrates present in dormant raspberry cane and bud tissues is available. The objective of this study was to examine seasonal changes in carbohydrates and the relationship between carbohydrates and cold hardiness in canes and flower buds of three raspberry cultivars.

\section{Materials and Methods}

Plant material. Canes of raspberry cultivars 'Maurin Makea', 'Ottawa' and 'Muskoka' were sampled from the field at 1-month intervals from Oct. 1996 to Apr. 1997 to determine their cold hardiness and carbohydrate contents. 'Ottawa' and 'Muskoka' were selected since they are the standard cultivars grown commercially in Finland. 'Maurin Makea' is a new Finnish cultivar presumably originated as an open-pollinated seedling from a single cross or several crosses between wild Finnish raspberry and cultivated varieties (Aaltonen et al., 1996). Overwintering canes were collected from three blocks of a raspberry cultivar trial at the Agricultural Research Centre of Finland, Häme Research Station, Pälkäne (latitude, $61^{\circ} 20^{\prime} \mathrm{N}$; longitude, $24^{\circ} 13^{\prime} \mathrm{E}$ ). The trial was established in 1992 on a fine sandy loam as a randomized complete block design with three blocks. Canes were sampled on seven dates: 7 Oct., 7 Nov., 1 Dec., 6 Jan., 3 Feb., 3 Mar., and 10 Apr. Prevailing weather conditions were characterized by very low temperatures at the end of December, then a warm period followed by low temperatures in February (Fig. 1).

For determination of cold hardiness, sample canes (two to three canes per cultivar and block) were sectioned into 15- to 20$\mathrm{cm}$-long pieces, except for the basal and terminal 20 to $30 \mathrm{~cm}$ of each shoot, which were discarded. For analysis of carbohydrates, a three-node section was taken from the middle part of five canes per cultivar and block. The samples were packed in polyethylene bags and placed on ice in styrofoam boxes for transportation to the University of Helsinki. Freezing tests were initiated on the day of sampling. Samples for carbohydrate analysis were dipped in

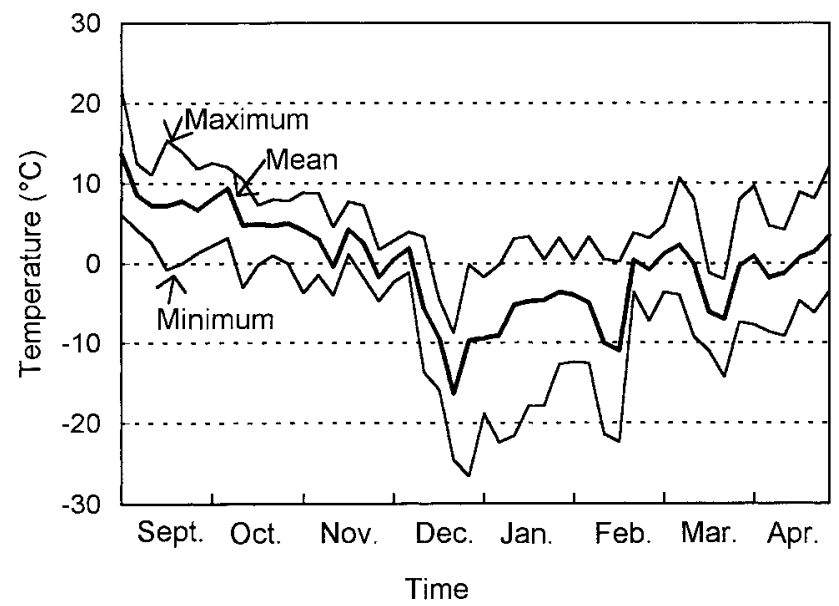

Fig. 1. Maximum, minimum, and mean temperatures as averages of 5-d periods during Winter 1996-97 at the Agricultural Research Centre of Finland, Häme Research Station, Pälkäne. liquid nitrogen and stored at $-80{ }^{\circ} \mathrm{C}$ until used for analysis.

DETERMINATION OF COLD HARDINESS. Cold hardiness of both canes and buds was determined by controlled freezing of the samples and the subsequent visual evaluation of injuries, as described by Palonen and Lindén (1999). Winter injury to canes in the field was evaluated using an arbitrary scale from 0 (no living canes) to 9 (no injury) on 30 May, after growth had resumed.

Analysis of CARbohydrates. Samples were freeze-dried and canes and buds separately ground into fine powder with an electric mill (Tecator cyclone sample mill, Tecator, Sweden). For starch analysis, soluble carbohydrates were extracted three times from $10 \mathrm{mg}$ of ground tissue with $2 \mathrm{~mL}$ ultrapure water (Milli-Q PF Plus ultrapure water system, Millipore S.A., Molsheim, France) for $30 \mathrm{~min}$ followed by centrifugation for $10 \mathrm{~min}$ at $1500 \mathrm{~g}_{\mathrm{n}}$. Starch in the pellets was analyzed by enzymatic hydrolysis (Volenec et al., 1991). One milliliter acetate buffer ( $\mathrm{pH} 4.5)$ was added to each sample, and samples were placed in a boiling water bath for $15 \mathrm{~min}$ to gelatinize starch. Starch was hydrolyzed with 50 units of amyloglucosidase (Sigma, St. Louis, Mo.) at $55^{\circ} \mathrm{C}$ for $20 \mathrm{~h}$. Samples were centrifuged $\left(10 \mathrm{~min}\right.$ at $\left.1500 \mathrm{~g}_{\mathrm{n}}\right)$, and Trinder reagent (Sigma) was used to quantify glucose in the supernatant. Original starch concentration was estimated as glucose equivalents.

For soluble carbohydrate analysis, $1 \mathrm{mg}$ of xylose was added as an internal standard to $50 \mathrm{mg}$ of ground tissue. Bud samples from three blocks were pooled, and two separate subsamples were analyzed to achieve an adequate sample size. Soluble carbohydrates were extracted three times with $4 \mathrm{~mL} 80 \%$ ethanol for $40 \mathrm{~min}$ followed by centrifugation for $10 \mathrm{~min}$ at $1500 \mathrm{~g}_{\mathrm{n}}$. Extraction was initiated with incubation in a $70^{\circ} \mathrm{C}$ water bath for $10 \mathrm{~min}$ to inactivate invertase, then continued at room temperature $\left(22^{\circ} \mathrm{C}\right)$. Supernatants were collected, evaporated to dryness in vacuo and resuspended in $500 \mu \mathrm{L}$ ultrapure water. The solution was then filtered through a filter with $0.45-\mu \mathrm{m}$ pores and analyzed using high-performance liquid chromatography (HPLC) [Varian Vista 5500 (Varian, Palo Alto, Calif.) with RI-detector HP 1047A (Hewlett Packard Gmbh, Waldbronn, Germany) and Merck Hitachi D-2500 chromato-integrator (Merck, Darmstadt, Germany)]. The mobile phase consisted of $80 \%(\mathrm{v} / \mathrm{v})$ acetonitrile in water at a flow rate of $1.2 \mathrm{~mL} \cdot \mathrm{min}^{-1}$. The column (Waters Spherisorb S5 Amino, $4.6 \mathrm{~mm} \times 25.0 \mathrm{~cm}$, Waters Co, Milford, MA, USA) was operated at $40{ }^{\circ} \mathrm{C}$. Peaks were identified and quantified by comparison with retention times, and peak areas relative to standards of sucrose, glucose, fructose, raffinose, and stachyose.

Statistical analysis. To observe differences among cultivars, cold hardiness data $\left(\mathrm{LT}_{50}\right)$ and data regarding the carbohydrate concentrations and the ratio of sucrose to glucose plus fructose were subjected to analysis of variance and means separated by the S-N-K test (Steel and Torrie, 1980). This was done separately for each sampling time and buds and canes, using GLM procedures of SAS (SAS Inst., Inc., 1989). Correlation analyses between $\mathrm{LT}_{50}$, the mean temperature during a 5-d period preceding sampling and carbohydrate concentrations were performed using the CORR procedure of SAS.

\section{Results}

Cold hardiness. Maximum cold hardiness of raspberry (except for 'Maurin Makea' canes) occurred in January (Table 1). Differences in cane cold hardiness among raspberry cultivars 
Table 1. Cold hardiness ( $\mathrm{LT}_{50}$ in controlled freezing) (Palonen and Lindén, 1999), and the ratio of sucrose to glucose plus fructose in canes and buds of three red raspberry cultivars from October to April. Within sampling times and tissue type (upper case letters for canes, lower case letters for buds), values marked with the same letter are not significantly different at $P=0.05$ by the $\mathrm{S}-\mathrm{N}-\mathrm{K}$ test. Absence of letters indicates no significant differences.

\begin{tabular}{|c|c|c|c|c|c|c|}
\hline \multirow{2}{*}{$\begin{array}{l}\text { Sampling } \\
\text { time }\end{array}$} & \multicolumn{2}{|c|}{ 'Maurin Makea' } & \multicolumn{2}{|c|}{ 'Ottawa' } & \multicolumn{2}{|c|}{ 'Muskoka' } \\
\hline & Canes & Buds & Canes & Buds & Canes & Buds \\
\hline & \multicolumn{6}{|c|}{ Cold hardiness $\left(\mathrm{LT}_{50},{ }^{\circ} \mathrm{C}\right)$} \\
\hline 7 Oct. & -19.2 & -15.0 & -20.8 & -17.5 & -17.5 & -16.7 \\
\hline 7 Nov. & -22.5 & -19.2 & -24.2 & -21.1 & -26.6 & -21.7 \\
\hline $1 \mathrm{Dec}$. & -27.5 & -21.6 & -30.3 & -25.0 & -28.1 & -23.3 \\
\hline 6 Jan. & $-28.6 \mathrm{~B}$ & $-24.2 \mathrm{~b}$ & $-37.2 \mathrm{~A}$ & $-31.6 \mathrm{a}$ & $-34.2 \mathrm{~A}$ & $-27.4 b$ \\
\hline 3 Feb. & $-36.3 \mathrm{~A}$ & $-24.2 \mathrm{ab}$ & $-31.6 \mathrm{AB}$ & $-26.4 \mathrm{a}$ & $-28.6 \mathrm{~B}$ & $-22.5 b$ \\
\hline 3 Mar. & -25.8 & $-16.2 \mathrm{~b}$ & -26.4 & $-18.9 \mathrm{a}$ & -26.4 & $-20.8 \mathrm{a}$ \\
\hline \multirow[t]{2}{*}{10 Apr. } & -23.1 & $-5.0 \mathrm{c}$ & -25.6 & $-13.1 \mathrm{~b}$ & -23.4 & $-17.5 \mathrm{a}$ \\
\hline & \multicolumn{6}{|c|}{ Ratio sucrose/(glucose+fructose) } \\
\hline 7 Oct. & $0.27 \mathrm{C}$ & 0.04 & $0.73 \mathrm{~A}$ & 0.06 & $0.42 \mathrm{~B}$ & 0.00 \\
\hline 7 Nov. & $0.60 \mathrm{~B}$ & $0.18 \mathrm{~b}$ & $1.28 \mathrm{~A}$ & $0.49 \mathrm{a}$ & $0.39 \mathrm{~B}$ & $0.14 \mathrm{~b}$ \\
\hline 1 Dec. & $0.66 \mathrm{C}$ & $0.18 \mathrm{~b}$ & $0.82 \mathrm{~B}$ & $0.33 \mathrm{a}$ & $0.97 \mathrm{~A}$ & $0.36 \mathrm{a}$ \\
\hline 6 Jan. & $0.36 \mathrm{~B}$ & $0.27 \mathrm{ab}$ & $0.67 \mathrm{~A}$ & $0.30 \mathrm{a}$ & $0.50 \mathrm{AB}$ & $0.23 \mathrm{~b}$ \\
\hline 3 Feb. & $0.27 \mathrm{~B}$ & $0.13 \mathrm{~b}$ & $1.00 \mathrm{~A}$ & $0.30 \mathrm{a}$ & $0.51 \mathrm{~B}$ & $0.28 \mathrm{a}$ \\
\hline 3 Mar. & $0.38 \mathrm{~B}$ & $0.05 \mathrm{~b}$ & $1.17 \mathrm{~A}$ & $0.08 \mathrm{a}$ & $0.43 \mathrm{~B}$ & $0.05 \mathrm{~b}$ \\
\hline 10 Apr. & 0.81 & $0.29 \mathrm{a}$ & 0.72 & $0.25 \mathrm{~b}$ & 0.38 & $0.27 \mathrm{ab}$ \\
\hline
\end{tabular}

were observed in January and February. Cultivar differences in bud cold hardiness were pronounced from January to April; overall, the least hardy buds were observed in 'Maurin Makea'. Spring evaluation of winter injury to canes in the field revealed differences among cultivars $\left(\mathrm{F}_{2,6}=8.17, P=0.019\right)$. 'Maurin Makea' suffered more winter injury (mean rating 4.7) compared to 'Ottawa' (8.3) and 'Muskoka' (8.1).

Carbohydrates. Starch, sucrose, glucose, fructose, raffinose, and stachyose were present in raspberry canes and buds (Table 2). Starch declined during fall (Fig. 2). In canes, starch was barely detectable in February, but increased thereafter (Fig. 2A). In buds, starch was not present in midwinter (Fig. 2B). Total soluble carbohydrates (calculated as the total concentration of sucrose, glucose, and fructose) increased in the fall, but declined in spring until increasing again in April (Fig. 2). Buds had higher concentrations of total soluble carbohydrates than canes. Highest concentrations of soluble carbohydrates were in canes from December to February ( 73 to $89 \mathrm{mg} \cdot \mathrm{g}^{-1}$ dry weight) and in buds in January (113 to $131 \mathrm{mg} \cdot \mathrm{g}^{-1}$ dry weight). Cultivar differences were observed for canes in November, February, and March, and for buds in December and March.

Highest relative increase was observed in the concentration of sucrose (Figs. 3-5). Sucrose increased from 5 to 9 to 29 to 43 $\mathrm{mg} \cdot \mathrm{g}^{-1}$ dry weight in canes, and from 0 to 3 to 24 to $30 \mathrm{mg} \cdot \mathrm{g}^{-1} \mathrm{dry}$ weight in buds. Sucrose content was consistently higher in canes than buds. Cultivar differences were observed in canes in Octo- ber, November, and January through March, and in buds from November through March. Overall, 'Ottawa' had the highest concentrations of sucrose and 'Maurin Makea' the lowest. The monosaccharides, glucose and fructose, accumulated in the fall but decreased in canes beginning in February, and in buds beginning in January (Fig. 4). In contrast to sucrose, fructose and glucose were more abundant in buds than in canes.

Small amounts of raffinose were detected in the samples (Table 2). Only data for canes are presented in Fig. 5. Raffinose increased in the fall and reached the highest concentrations in December. Traces of stachyose were detected in cane and bud tissues. The occurrence of stachyose was more frequent in midwinter than in the fall or spring (data not shown).

The ratio of sucrose to glucose plus fructose was consistently higher in canes than in buds (Table 1). Cultivar differences were observed at all sampling times, except for canes in April and buds in October. The ratio of sucrose to glucose plus fructose was highest in 'Ottawa' at most of the sampling times.

RELATIONSHIP BETWEEN COLD HARDINESS, AIR TEMPERATURE, AND CARBOHYDRATES. When the cultivars were pooled, there was a positive correlation between $\mathrm{LT}_{50}$ and the amount of starch, but a negative correlation between $\mathrm{LT}_{50}$ and the amounts of total soluble carbohydrates, sucrose, glucose, and fructose (Table 3). Least significant correlation coefficients were observed in 'Maurin Makea'. $\mathrm{LT}_{50}$ was more closely related to preceding air temperature in canes than in buds. Carbohydrate concentrations (espe-

Table 2. Carbohydrates present in cane and bud tissues of three red raspberry cultivars from October to April.

\begin{tabular}{|c|c|c|c|c|c|c|}
\hline \multirow[b]{3}{*}{ Carbohydrate } & \multicolumn{6}{|c|}{ Concn $\left[(\min / \max )\left(\mathrm{mg} \cdot \mathrm{g}^{-1}\right.\right.$ dry $\left.\left.w \mathrm{t}\right)\right]$} \\
\hline & \multicolumn{2}{|c|}{ 'Maurin Makea' } & \multicolumn{2}{|c|}{ 'Ottawa' } & \multicolumn{2}{|c|}{ 'Muskoka' } \\
\hline & Canes & Buds & Canes & Buds & Canes & Buds \\
\hline Starch & $0-49.7$ & $0-55.2$ & $1.7-43.0$ & $0-56.3$ & $0.7-53.3$ & $0-47.1$ \\
\hline Sucrose & $4.8-29.0$ & $1.5-24.1$ & $9.4-43.0$ & $2.5-30.3$ & $8.4-39.7$ & $0-27.5$ \\
\hline Glucose & $9.5-24.2$ & $16.8-44.5$ & $6.8-24.5$ & $19.2-47.0$ & $10.3-27.5$ & $17.6-40.0$ \\
\hline Fructose & $10.4-26.3$ & $16.4-51.1$ & $6.3-25.3$ & $19.8-54.0$ & $10.3-26.9$ & $18.7-50.1$ \\
\hline Raffinose & $0.8-6.6$ & 0 -traces & $0.3-5.3$ & 0 -traces & $2.0-7.8$ & 0 -traces \\
\hline Stachyose & 0 -traces & 0 -traces & 0 -traces & 0 -traces & 0 -traces & 0 -traces \\
\hline
\end{tabular}


cially starch) were more closely related to preceding air temperature than to $\mathrm{LT}_{50}$, particularly in buds. Amounts of starch were negatively correlated with amounts of total soluble carbohydrates ( $r=-0.62, P<0.001$ in canes, $r=-0.76, P<0.001$ in buds).

\section{Discussion}

This study demonstrated that starch, sucrose, glucose, fructose, and minor amounts of raffinose and stachyose occur in overwintering raspberry cane and bud tissues. It was also found that the concentrations of these carbohydrates change seasonally. Similar findings have not been reported previously. However, our results agree with findings of Burley (1961), who observed sucrose along with some glucose and fructose, and traces of raffinose in raspberry bark during the growing season. Zimmermann and Ziegler (1975) observed $20 \%$ to $30 \%$ (w/v) of sucrose and $0.5 \%$ to $2 \%$ of raffinose and stachyose in sieve-tube exudate of Rubus thibetanus Franch.

Seasonal changes in carbohydrate content were related to changes in cold hardiness and air temperatures. This is similar to a report of total sugar content in raspberry (Bennett and Weeks, 1960; Jennings and Carmichael, 1975) and several other plant species. Starch declined but soluble carbohydrates accumulated when cold hardiness increased in the fall, whereas an opposite
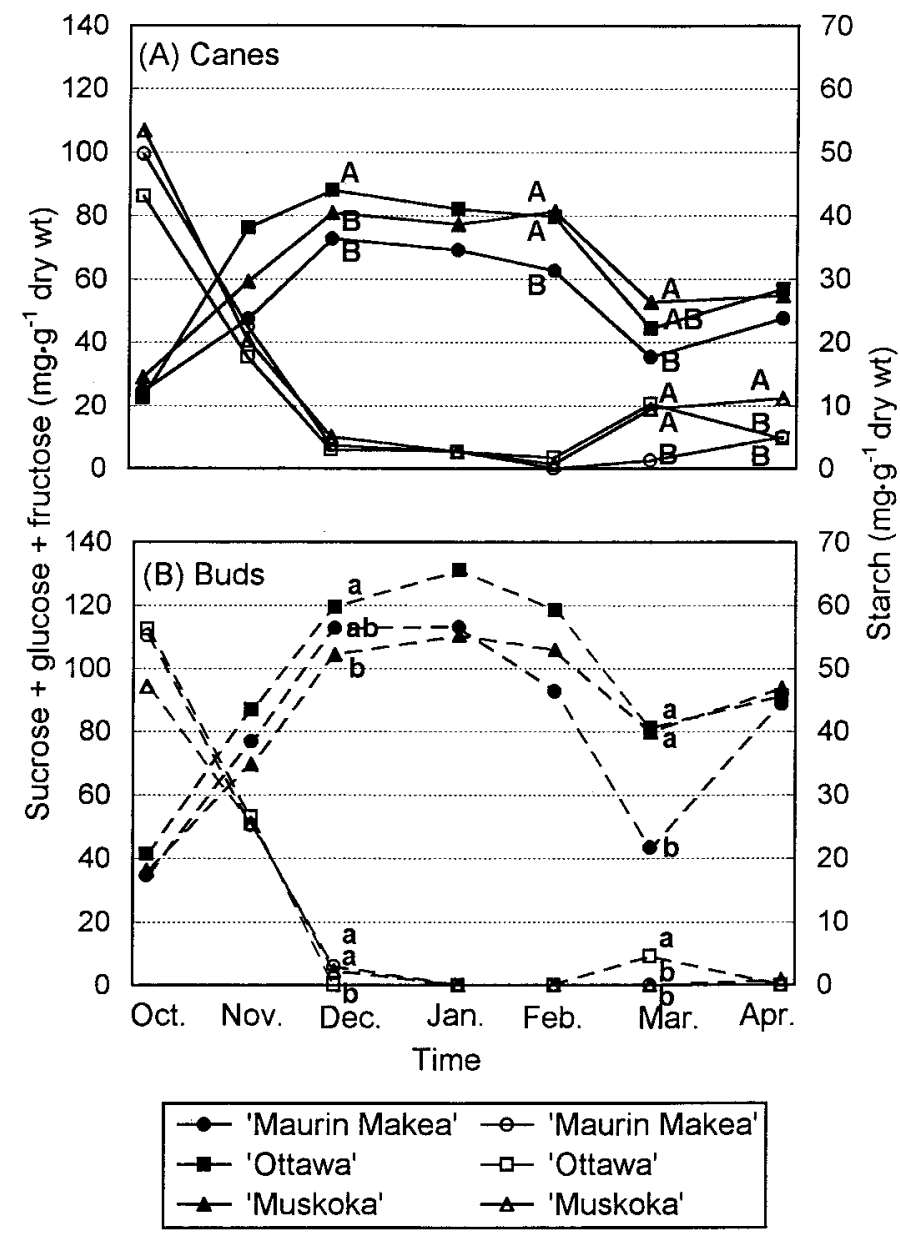

Fig. 2. Concentrations of starch (open symbols) and total soluble carbohydrates (closed symbols) in (A) canes and (B) buds of three raspberry cultivars from October to April. For each sampling time, values marked with the same letter are not significantly different at $P \leq 0.05$ by the S-N-K test. Absence of letters indicates no significant differences among cultivars. phenomenon occurred in spring. Starch almost disappeared from the canes and entirely disappeared from the buds during the winter months. The increase in the amount of soluble carbohydrates cannot, however, be explained solely by hydrolysis of starch (Fig. 2). Lowest $\mathrm{LT}_{50}$ values were observed generally in January following a period of very low temperatures at the end of December, and coincided with the highest concentrations of soluble carbohydrates in the buds; whereas in canes, soluble carbohydrates did not increase after December. Total soluble carbohydrates were more abundant in raspberry buds than in canes because the amounts of glucose and fructose were higher. This is clearly expressed in the ratios of sucrose to glucose plus fructose presented in Table 1 and may reflect the different anatomy and mechanisms of frost survival in canes and buds. The maximum concentration of total sugars observed during this study was 73 to $89 \mathrm{mg} \cdot \mathrm{g}^{-1}$ dry weight in canes, and 113 to 131 $\mathrm{mg} \cdot \mathrm{g}^{-1}$ dry weight in buds. The maximum concentrations of 10.6\% (Bennett and Weeks, 1960), 8\% (Crandall et al., 1974), and $18 \%$ (Jennings and Carmichael, 1975) total sugars in raspberry canes in midwinter have been reported. The different cultivars and methods of analysis may explain the differences. In the present study, increases in starch content were observed in March and April, but these occurred in February in Scotland (Jennings and Carmichael, 1975). The disparity is likely due to differences in climatic conditions. A simultaneous increase in starch contents and the primary translocatable carbohydrate su-

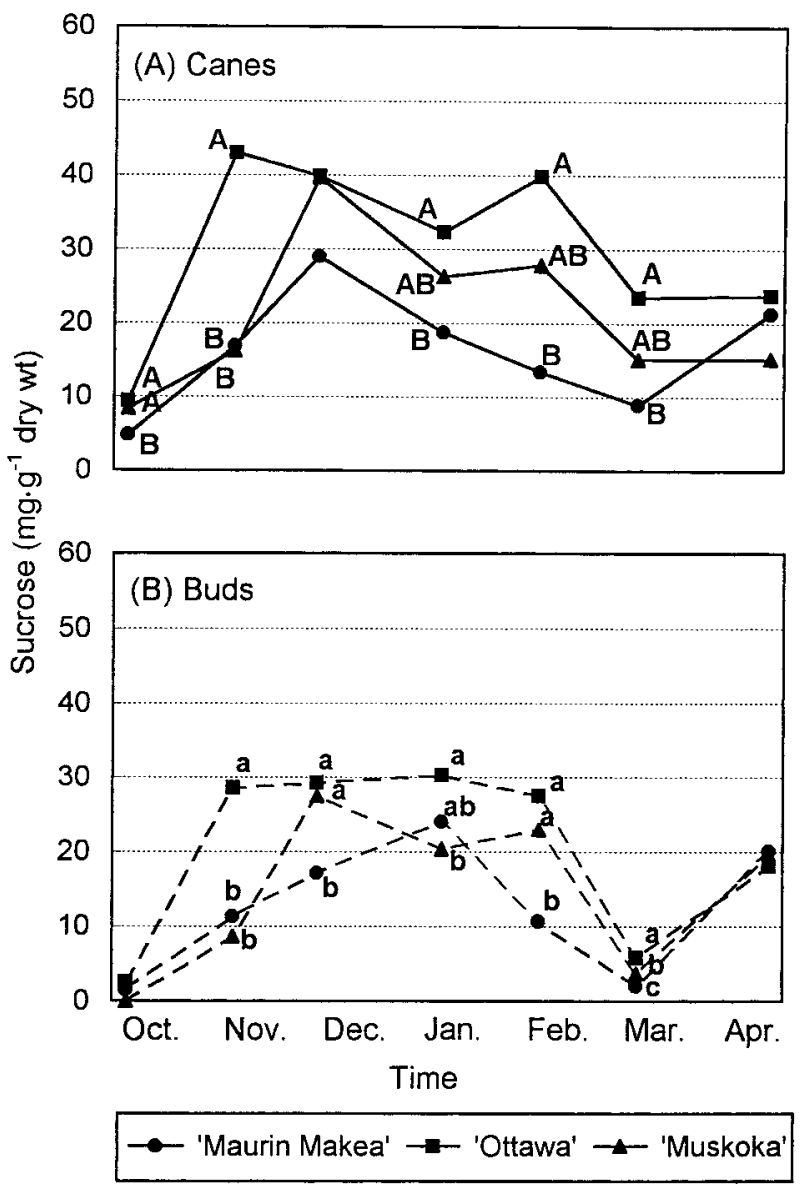

Fig. 3. Concentration of sucrose in (A) canes and (B) buds of three raspberry cultivars from October to April. For each sampling time, values marked with the same letter are not significantly different at $P \leq 0.05$ by the S-N-K test. Absence of letters indicates no significant differences among cultivars. 
crose in raspberry buds may be explained by mobilization of root carbohydrate reserves to support the beginning of new growth. An increase in starch content coincides with budbreak in redosier dogwood (Ashworth et al., 1993) and in Forsythia sp. (Flinn and Ashworth, 1995).

Accumulation of total soluble carbohydrates was caused mainly by an increase in sucrose. On average, a 5-fold increase was observed in canes and a 12-fold increase in buds. Buds were very low in sucrose in October (0 to $3 \mathrm{mg} \cdot \mathrm{g}^{-1}$ dry weight). After increasing during the winter, sucrose disappeared almost entirely in March before appearing again in April. Glucose and fructose accumulated to a lesser extent than sucrose. The highest concentrations were found coincident with maximum cold hardiness in January. The disaccharide sucrose is a more effective cryoprotectant than monosaccharides (Crowe et al., 1990). In cloudberry, sucrose correlated with cold hardiness and was the major carbohydrate contributing to changes in sugar content (Kaurin et al., 1981).

Accumulation of raffinose and stachyose was observed, as well, and the pattern of raffinose accumulation in canes most closely resembled that of sucrose accumulation. The effect of raffinose accumulation may be to facilitate vitrification, i.e., intracellular glass formation instead of crystallization. If sucrose crystallizes, as may happen during drying, the hydroxyl groups of sucrose are not available to replace water in the phospholipid
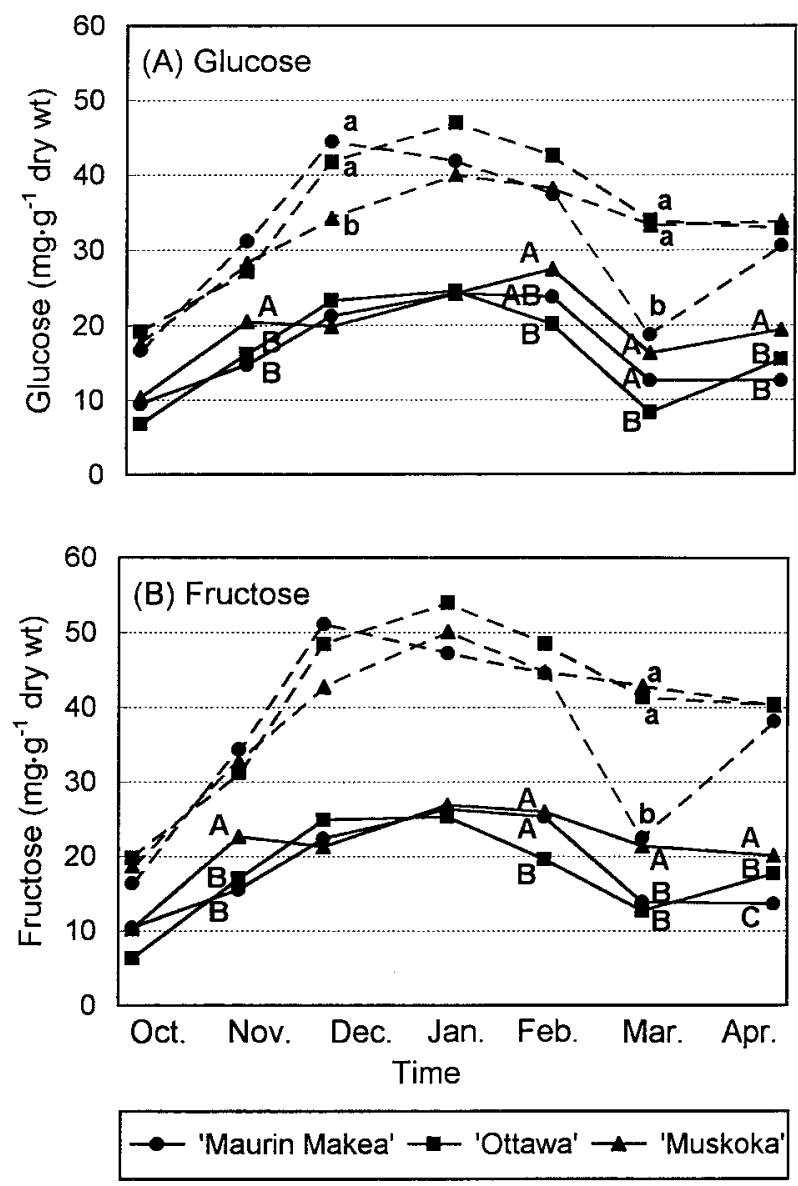

Fig. 4. Concentrations of (A) glucose and (B) fructose in canes (solid line) and buds (dotted line) of three raspberry cultivars from October to April. For each sampling time, values (canes upper case letters and buds lower case letters) marked with the same letter are not significantly different at $P \leq 0.05$ by the $\mathrm{S}$ $\mathrm{N}-\mathrm{K}$ test. Absence of letters indicates no significant differences among cultivars. groups of the membrane (Koster and Leopold, 1988). Although sucrose is a principal agent in stabilizing membranes, the larger oligosaccharides may keep sucrose from crystallizing (Koster and Leopold, 1988). According to Smythe (1967), among many sugars and other organic compounds, raffinose and stachyose are the most effective inhibitors of sucrose crystal growth and are efficient in even small amounts. In the induction of high-temperature desiccation tolerance in corn (Zea mays L.) seeds, a raffinose to sucrose ratio of $9 \%$ is optimal for membrane stability (Chen and Burris, 1990). Hence, despite their small relative concentrations, raffinose and stachyose may have a decisive role also in freezing tolerance. Correlation of raffinose family oligosaccharides to cold hardiness has been reported previously (Ashworth et al., 1993; Flinn and Ashworth, 1995; Hamman et al., 1996; Imanishi et al. 1998; Stushnoff et al., 1993).

Although correlation coefficients between cold hardiness and carbohydrates were highly significant, the correlation analysis as such does not prove a causal relationship between these variables. The highest correlation coefficients were observed between $\mathrm{LT}_{50}$ and starch in canes, and between $\mathrm{LT}_{50}$ and total soluble carbohydrates, fructose, and glucose in buds. Carbohydrate concentrations were closely related to preceding air temperatures. Changes in both cold hardiness and carbohydrates probably are induced by weather changes. The maximum concentrations of carbohydrates and maximum cold hardiness were not observed simultaneously. At some of the sampling times, significant differences in cold hardiness were observed, although there were no differences in carbohydrate levels. It is evident from these data that to better understand the relationship between cold hardiness and carbohydrates, much higher frequency of sampling is required.

Genetically, 'Maurin Makea' differs greatly from 'Ottawa' and 'Muskoka' (Aaltonen et al., 1996; Darrow, 1967). Based on the field observations, 'Maurin Makea' was the least hardy cultivar in this study and suffered more winter injury than 'Ottawa' or 'Muskoka'. In a previous study we observed differences in dehardening and the capacity to reharden in the same raspberry cultivars as used in the current study (Palonen and Lindén, 1999). After January, 'Maurin Makea' lost hardiness quickly, and its rehardening ability was diminished; whereas 'Ottawa' maintained its hardiness latest in spring, and 'Muskoka' was intermediate between these cultivars. We failed, however, to explain these cultivar differences in dehardening and rehardening by changes in dormancy status. The carbohydrate concentrations

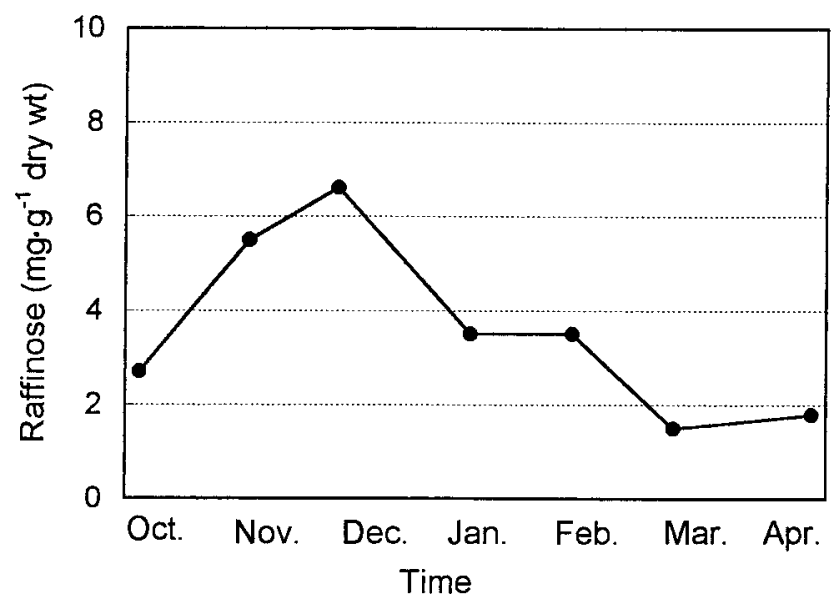

Fig. 5. Mean concentration of raffinose in canes of three raspberry cultivars from October to April. No differences between cultivars were observed. 
Table 3. Pearson correlation coefficients between cold hardiness $\left(\mathrm{LT}_{50}\right)$, the mean temperature during a 5-d period preceding sampling, and the concentrations of starch, total soluble carbohydrates, sucrose, glucose, and fructose in canes and buds of three red raspberry cultivars.

\begin{tabular}{|c|c|c|c|c|c|c|c|c|c|c|c|c|}
\hline \multirow[b]{2}{*}{ Cultivar } & \multicolumn{6}{|c|}{ Canes } & \multicolumn{6}{|c|}{ Buds } \\
\hline & $\mathrm{LT}_{50}$ & Starch & Total & Sucrose & Glucose & Fructose & $\mathrm{LT}_{50}$ & Starch & Total & Sucrose & Glucose & Fructose \\
\hline \multicolumn{13}{|l|}{ 'Maurin Makea' } \\
\hline $\mathrm{LT}_{50}$ & & $0.65^{* * * *}$ & NS & NS & $-0.56^{* * *}$ & $-0.50 *$ & & NS & NS & NS & $-0.51^{*}$ & $-0.43^{*}$ \\
\hline Temperature & $0.70^{* * * *}$ & $0.81^{* * * *}$ & $-0.62^{* * *}$ & NS & $-0.65^{* * *}$ & $-0.63^{\text {**** }}$ & NS & $0.84^{* * * *}$ & $-0.75^{* * *}$ & $-0.72^{* * * *}$ & $-0.69^{* * *}$ & $-0.74^{* * * *}$ \\
\hline \multicolumn{13}{|l|}{ 'Ottawa' } \\
\hline $\mathrm{LT}_{50}$ & & $0.67^{* * * *}$ & $-0.52^{*}$ & NS & $-0.59^{* * * *}$ & $-0.56^{* *}$ & & NS & $-0.73^{* * * *}$ & $-0.65^{* * * *}$ & $-0.73^{* * *}$ & $-0.65^{* * * *}$ \\
\hline Temperature & $0.85^{* * * *}$ & $0.83^{* * * *}$ & $-0.51 *$ & NS & $-0.64^{* * *}$ & $-0.63^{* * * *}$ & $0.60^{* * * *}$ & $0.85^{* * * *}$ & $-0.86^{* * *}$ & $-0.57^{*}$ & $-0.92^{* * * *}$ & $-0.92^{* * * *}$ \\
\hline \multicolumn{13}{|l|}{ 'Muskoka' } \\
\hline $\mathrm{LT}_{50}$ & & $0.77^{* * *}$ & $-0.59^{* * *}$ & $-0.52^{*}$ & $-0.53^{*}$ & $-0.55^{* *}$ & & $0.51^{*}$ & $-0.69^{* * * *}$ & $-0.52^{*}$ & $-0.71^{* * *}$ & $-0.72^{* * * *}$ \\
\hline Temperature & $0.77^{* * * *}$ & $0.83^{* * * *}$ & $-0.57^{* * *}$ & $-0.51^{*}$ & $-0.54^{*}$ & $-0.50^{*}$ & $0.68^{* * * *}$ & $0.83^{* * * *}$ & $-0.91^{* * * *}$ & $-0.75^{\text {**** }}$ & $-0.91^{* * * *}$ & $-0.89^{* * * *}$ \\
\hline \multicolumn{13}{|l|}{ All cultivars } \\
\hline $\mathrm{LT}_{50}$ & & $0.69^{* * * *}$ & $-0.51^{* * * *}$ & $-0.38^{* * *}$ & $-0.53^{* * * *}$ & $-0.50^{* * * *}$ & & $0.27^{*}$ & $-0.58^{* * * *}$ & $-0.44^{* * * *}$ & $-0.62^{* * * *}$ & $-0.57^{* * * *}$ \\
\hline Temperature & $0.76^{* * * *}$ & $0.82^{* * * *}$ & $-0.54^{* * * *}$ & $-0.35^{* * *}$ & $-0.60^{* * * *}$ & $-0.58^{* * * *}$ & $0.46^{* * * *}$ & $0.84^{* * * *}$ & $-0.81^{* * *}$ & $-0.63^{* * * *}$ & $-0.81^{* * * *}$ & $-0.83^{* * * *}$ \\
\hline
\end{tabular}

determined offer at least part of the explanation, because they were well correlated with the cold-hardiness characteristics of these cultivars. 'Maurin Makea' had lower concentrations of total soluble carbohydrates and sucrose in the canes throughout the experiment and in the buds after January. However, 'Ottawa' generally had the highest concentrations of total soluble carbohydrates and sucrose, and the highest ratio of sucrose to glucose plus fructose. Although during the winter 'Maurin Makea' had lower levels of sucrose than the other cultivars, a relative increase in sucrose content of its canes from March to April was observed. This may be an indication of metabolic activity starting earlier than that of the other cultivars. This hypothesis would, however, require further study with more frequent sampling during late winter and spring.

In conclusion, results herein provide further evidence of the importance of carbohydrate reserves on winter survival of raspberry. A many-fold increase in soluble carbohydrates, especially sucrose, but also accumulation of glucose, fructose, raffinose, and stachyose coincided with cold acclimation. High concentrations of soluble carbohydrates, sucrose, and a high ratio of sucrose to glucose plus fructose were characteristic of a hardy raspberry cultivar. Cultural practices that enhance accumulation of carbohydrates in raspberry plants should be developed and tested.

\section{Literature Cited}

Aaltonen, M., M. Takala, and M. Uosukainen. 1996. Maurin Makea vadelmalajike_-herkku tuoremarkkinoille. Puutarha 99:387.

Anchordoguy, T.J., A.S. Rudolph, J.F. Carpenter, and J.H. Crowe. 1987. Modes of interaction of cryoprotectants with membrane phospholipids during freezing. Cryobiology 24:324-331.

Ashworth, E.N., V.E. Stirm, and J.J. Volenec. 1993. Seasonal variations in soluble sugars and starch within woody stems of Cornus sericea $\mathrm{L}$. Tree Physiol. 13:379-388.

Bennett, E. and W.D. Weeks. 1960. A partial chemical analysis of two varieties of raspberry canes which differ in winter hardiness. Proc. Amer. Soc. Hort. Sci. 76:366-369.

Burley, J.W.A. 1961. Carbohydrate translocation in raspberry and soybean. Plant Physiol. 36:820-824.

Chen, Y. and J.S. Burris. 1990. Role of carbohydrates in desiccation tolerance and membrane behavior in maturing maize seed. Crop Sci. 30:971-975.

Crandall, P.C., D.F. Allmendinger, J.D. Chamberlain, and K.A. Biderbost. 1974. Influence of cane number and diameter, irrigation, and carbohy- drate reserves on the fruit number of red raspberries. J. Amer. Soc. Hort. Sci. 99:524-526.

Crowe, J.H., J.F. Carpenter, L.M. Crowe, and T.J. Anchordoguy. 1990. Are freezing and dehydration similar stress vectors? A comparison of modes of interaction of stabilizing solutes with biomolecules. Cryobiology 27:219-231.

Crowe, J.H., L.M. Crowe, J.F. Carpenter, and C. Aurell Wistrom. 1987. Stabilization of dry phospholipid bilayers and proteins by sugars. Biochem. J. 242:1-10.

Darrow, G.M. 1967. The cultivated raspberry and blackberry in North America-Breeding and improvement. Amer. Hort. Mag. 46:203218.

Doughty, C.C., P.C. Crandall, and C.H. Shanks, Jr. 1972. Cold injury to red raspberries and the effect of premature defoliation and mite damage. J. Amer. Soc. Hort. Sci. 97:670-673.

Flinn, C.L. and E.N. Ashworth. 1995. The relationship between carbohydrates and flower bud hardiness among three Forsythia taxa. J. Amer. Soc. Hort. Sci. 120:607-613.

Hamman, R.A., Jr., I.-E. Dami, T.M. Walsh, and C. Stushnoff. 1996. Seasonal carbohydrate changes and cold hardiness of Chardonnay and Riesling grapevines. Amer. J. Enol. Viticult. 47:31-36.

Ichiki, S. and H. Yamaya. 1982. Sorbitol in tracheal sap of dormant apple (Malus domestica Borkh.) shoots as related to cold hardiness, p. 181187. In: P.H. Li and A. Sakai (eds.). Plant cold hardiness and freezing stress: Mechanisms and crop implications. vol. 2. Academic Press, New York.

Imanishi, H.T., T. Suzuki, K. Masuda, and T. Harada. 1998. Accumulation of raffinose and stachyose in shoot apices of Lonicera caerulea $\mathrm{L}$. during cold acclimation. Scientia Hort. 72:255-263.

Jennings, D.L. and E. Carmichael. 1975. Some physiological changes occurring in overwintering raspberry plants in Scotland. Hort. Res. 14:103-108.

Kaurin, A., O. Junttila, and J. Hansen. 1981. Seasonal changes in frost hardiness in cloudberry (Rubus chamaemorus) in relation to carbohydrate content with special reference to sucrose. Physiol. Plant. 52:310 314.

Koster, K.L. and A.C. Leopold. 1988. Sugars and desiccation tolerance in seeds. Plant Physiol. 88:829-832.

Lasheen, A.M. and C.E. Chaplin. 1971. Biochemical comparison of seasonal variations in three peach cultivars differing in cold hardiness. J. Amer. Soc. Hort. Sci. 96:154-159.

Levitt, J. 1980. Responses of plants to environmental stresses. vol. 1. Chilling, freezing and high temperature stresses. Academic Press, New York.

Palonen, P. and L. Lindén. 1999. Dormancy, cold hardiness, dehardening, and rehardening in selected red raspberry cultivars. J. Amer. Soc. Hort. Sci. 124(4):341-346. 
Raese, J.T., M.W. Williams, and H.D. Billingsley. 1977. Sorbitol and other carbohydrates in dormant apple shoots as influenced by controlled temperatures. Cryobiology 14:373-378.

Raese, J.T., M.W. Williams, and H.D. Billingsley. 1978. Cold hardiness, sorbitol, and sugar levels of apple shoots as influenced by controlled temperature and season. J. Amer. Soc. Hort. Sci. 103:796-801.

Sakai, A. 1966. Seasonal variations in the amounts of polyhydric alcohol and sugar in fruit trees. J. Hort. Sci. 41:207-213.

Sakai, A. and S. Yoshida. 1968. The role of sugar and related compounds in variations of freezing resistance. Cryobiology 5:160-174.

Santarius, K.A. 1982. The mechanism of cryoprotection of biomembrane systems by carbohydrates, p. 475-486. In: P.H. Li and A. Sakai (eds.). Plant cold hardiness and freezing stress: Mechanisms and crop implications. vol. 2. Academic Press, New York.

SAS Institute, Inc. 1989. SAS/STAT user's guide. version 6. 4th ed. vol. 2. SAS Inst., Inc., Cary, N.C.

Smythe, B.M. 1967. Sucrose crystal growth. Austral. J. Chem. 21:10971114.

Steel, R.G.D. and J.H. Torrie. 1980. Principles and procedures of statistics. 2nd ed. McGraw-Hill, New York.
Stushnoff, C., R.L. Remmele, Jr., V. Essensee, and M. McNeil. 1993. Low temperature induced biochemical mechanisms: Implications for cold acclimation and de-acclimation, p. 647-657. In: M.B. Jackson and C.R. Black (eds.). Interacting stresses on plants in a changing climate. NATO ASI Ser., vol. I 16. Springer-Verlag, Berlin.

Tamassy, I. and M. Zayan. 1982. Seasonal changes in total sugars, reducing sugars and starch contents in relation to cold hardiness of some apricot varieties from different groups. Acta Hort. 121:125-139.

Volenec, J.J., P.J. Boyce, and K.L. Hendershot. 1991. Carbohydrate metabolism in taproots of Medicago sativa L. during winter adaptation and spring regrowth. Plant Physiol. 96:786-793.

Wallaart, R.A.M. 1980. Distribution of sorbitol in Rosaceae. Phytochemistry 19:2603-2610.

Wample, R.L. and A. Bary. 1992. Harvest date as a factor in carbohydrate storage and cold hardiness of Cabernet Sauvignon grapevines. J. Amer. Soc. Hort. Sci. 117:32-36.

Zimmermann, M.H. and H. Ziegler. 1975. List of sugars and sugar alcohols in sieve tube exudates, p. 480-503. In: M.H. Zimmermann and J.A. Milburn (eds.). Encyclopedia of plant physiology (new series). vol. 1. Springer-Verlag, Berlin. 